International Journal of Instruction e-ISSN: 1308-1470 • www.e-iji.net

Article submission code: 2020032111410

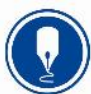

October $2021 \bullet$ Vol.14, No.4

p-ISSN: 1694-609X

pp. 209-222

Received: 21/03/2020

Revision: 04/03/2021
Accepted: 28/03/2021

OnlineFirst: 17/07/2021

\title{
Student Attitude and Mathematics Learning Success: A Meta-Analysis
}

\section{Harun}

Prof., Yogyakarta State University, Yogyakarta, Indonesia, harun@uny.ac.id

Badrun Kartowagiran

Prof., Yogyakarta State University, Yogyakarta, Indonesia, kartowagiran@uny.ac.id

\author{
Abdul Manaf \\ Doctoral student in Yogyakarta State University, Indonesia, \\ abdulmanaf.2017@student.uny.ac.id
}

Some students consider mathematics as a subject that is very difficult and frightening, so it results in the success of learning mathematics. There are two factors that cause students' success in learning mathematics, namely internal and external factors. Students' attitudes is one of the internal factors that determine the success of learning mathematics. This study aims to prove the effect of student attitude on mathematics learning success. This type of research is quantitative meta-analysis. The variables of this study are students'attitudes as independent variables and students' mathematics learning success as dependent variables. Sources of data obtained from various research results in Indonesia since 20102019. Twenty-two samples of research publications were taken from online databases (google scholar, national \& international journal) according to specified eligibility criteria. Data analysis using a meta-analysis approach. The results showed that there was a positive and significant influence on students' attitudes towards mathematics learning success, with the weight value of the effect size being within the specified confidence interval. The small amount of sampling error causes the effect size weight to be in the moderate category. These results have of course proven consistency and strengthened the theories or findings of previous researchers.

Keywords: student attitude, learning outcomes, learning achievement, mathematics, meta-analysis

\section{INTRODUCTION}

Mathematics is considered as the queen of science and has links with various other sciences (Atiyah, 1993). Mathematics is one of the basic lessons taught at every level of formal education, for example PAUD, SD, SMP, SMA, and University. Realizing the importance of the role of mathematics, it is hoped that every student can be able to

Citation: Harun., Kartowagiran, B., \& Manaf, A. (2021). Student attitude and mathematics learning success: A meta-analysis. International Journal of Instruction, 14(4), 209-222. https://doi.org/10.29333/iji.2021.14413a 
master mathematics in accordance with the demands of the curriculum being taught. But it is an undeniable fact that until now the mastery of students in Indonesia over mathematics subject matter is still relatively low. In the context of education, based on the World Bank's 2018 report the acquisition of PISA participants from Indonesia is far lower than the average OECD country as shown in figure 1 . The position of achieving the best value of Indonesian students is only the same as the lowest value of OECD countries. While Vietnam shows results that are superior to Indonesia (World Development Report, 2018).

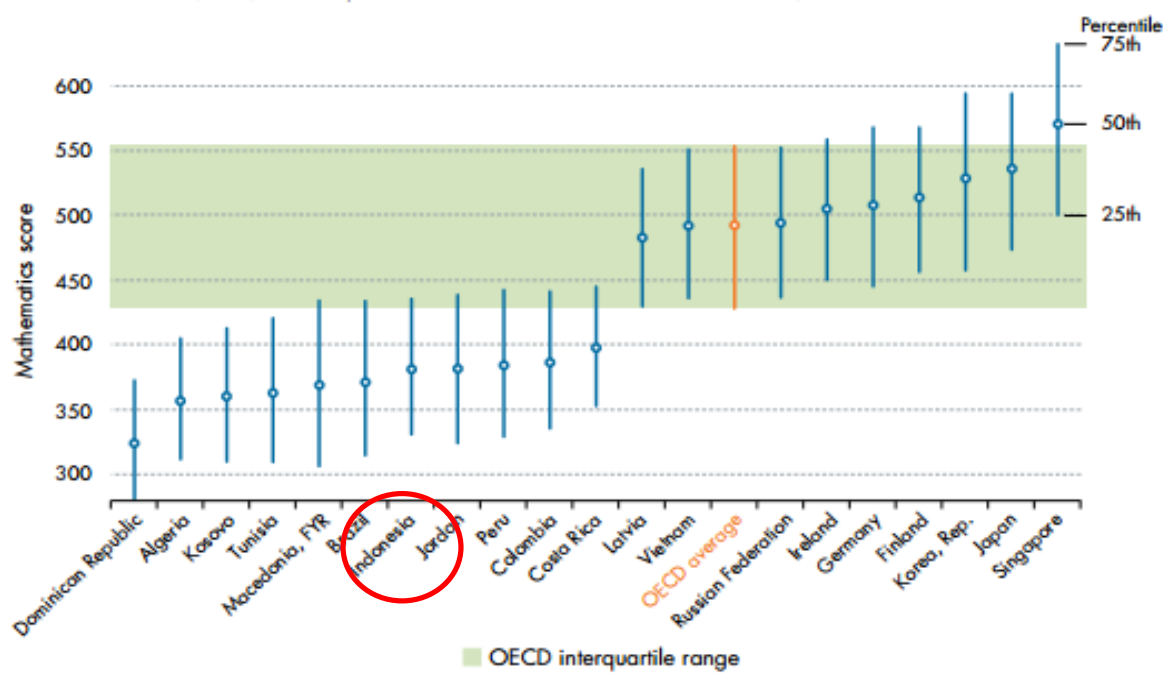

Figure 1

PISA assessment perforamance in 2015

Various efforts have been made by the Indonesian government and competent parties through the improvement of educational facilities and infrastructure as well as the improvement of mathematics learning methods. But in reality it has not shown significant changes. Some students still consider mathematics as a subject that is very difficult to learn or understand, so that it has an impact on the success of learning mathematics. The success of students' mathematics learning is influenced by both internal and external factors. Slameto (1995) states that external factors are socioeconomic, natural or physical environment, social environment, school environment, and family environment. While internal factors are talent factors (Mazana\&Mzomwe, 2019), or intelligence, motivation (Kirkham, 2019), roles, attitudes and interests. Many factors can affect the success of students' mathematics learning. However, among the factors that are generally considered more essential is the attitude of students (Peteros, et. al, 2019).

Students' attitudes is one of the factors that determine the success of students' mathematics learning (Capuno, et.al, 2019). A student who has a good attitude towards mathematics will have confidence (Makur, Prahmana, \& Gunur, 2019) focusing more 
attention than other subjects. Intensive focus on mathematics, allows students to study harder and ultimately achieve the desired results. And vice versa students who show less sympathetic attitude, are not passionate, and do not follow the process of teaching and learning mathematics in turn can make student learning outcomes or achievement low (Ozturk, 2014).

The positive attitude of mathematics students has shown to be, very influential on the success of mathematics students in Indonesia. This, shown from the results of several research results that have been published in Google Scholar's online database, include mathematics learning attitudes (Jemudin, 2019); and attitudes in learning mathematics (Ma'mun, 2017) affect mathematics learning achievement. Simplify scientific attitude (Haryaka \& Haslida, 2019); independent attitude (Mujiono \& Ladyawati, 2017); attitudes to mathematics (Sirajuddin, et. al., 2019); and constructive attitude (Labib, 2010) affect the learning outcomes of mathematics. The result of learning mathematics is the success obtained by each student in the field of mathematics after taking the teaching and learning process in one particular subject. Whereas mathematics learning achievement is the level of mastery of mathematics material achieved by students in one semester.

Based on the description above it can be concluded that students' attitudes influence the success of learning mathematics. So the authors are interested in conducting research with a quantitative meta-analysis approach to prove the effect of students' attitudes on the success of learning mathematics in Indonesia as well as to determine the value of the resulting effect size weight. Meta analysis can combine two or more published research results for statistical analysis. Meta-analysis is one of the right ways to provide information that can be accounted for in a timely manner.

\section{METHOD}

\section{Research Design}

This research is a quantitative meta-analysis (Hunter \& Schmidt, 2004). Combine two or more published research results for statistical analysis. Research publications relate to the effect of students attitude on mathematics learning success

\section{Eligibility Criteria}

Hunter \& Schmit (2004) stated that the completeness of information about artifacts is very important, so that corrections can be made in each individual study. The eligibility criteria used to filter the publication of research results online database are:

1. Must be the result of research in Indonesia

2. It must be the result of original research, not a review

3. Can be accessed on google scholar, national journal, and internasional journal

4. Publication at least since 2010

5. Available in Indonesian or English

6. Must be related to student attitude and success in learning mathematics

7. The variable of mathematics learning success is limited to mathematics learning outcomes and mathematics learning achievement 
8. Every research publication must have a minimum sample of 15 participants

9. Must have a correlation coefficient ( $r$ ) or a terminated coefficient that indicates the amount of influence produced by student attitude variables on the mathematics learning success variable

Thus, the nine criteria above are considered suffcient to be used in filtering or selecting research result (artifacts) that are the object of the meta-analysis.

\section{Data Collection}

Data collection in this study was conducted by studying the results of research on the influence of students' attitudes on learning outcomes in mathematics. The results of these studies are accessed via the internet in google scholar online database. The keywords used to make in the search are student attitude, mathematics learning outcomes, and student mathematics learning achievement. From the search results found 22 research publications that met the criteria specified above with the time span of publication from 2010 to 2019 (Table 1). Hunter \& Schimidt (2004) stated that if there were only 10 studies studied, it would be said to be a little. Therefore, this study involved 22 research titles, which means a lot can be said.

\section{Coding}

In this research coding needs to be done. The aim is to facilitate the author in the process of data analysis. Components in coding are information about the year of research, researcher or author, sample size $(\mathrm{N})$, correlation coefficient $(\mathrm{r})$ or terminated coefficient, and variables (independent and dependent)

\section{Data analysis}

The steps of data analysis in this study refer to the opinion of Hunter \& Schmidt (2004), Borenstein. et.al, (2009)., and Grasman (2017), namely calculating the mean population correlation, calculating the variance of the coefficient $r$, sampling error variance, calculating the estimated population correlation variance, calculating confidence intervals, effect sized based on correlations, forest plots, and publication bias / trim-fill analysis. To facilitate data analysis in this study using JASP software tools. 0.8. 4.0

\section{FINDINGS}

\section{Characteristics of Research Samples}

Based on the eligibility criteria determined above, as many as 22 research publications were obtained that met all the specified criteria. Research publications that will be used in the analysis are from 2010 to 2019, except for 2012 and 2013. The number of samples of each research publication is highly variable. The sample size is small with $\mathrm{N}$ $=18$, and the largest sample with $\mathrm{N}=360$. Participants in the research varied greatly, including junior high, MTs, vocational, and high school students. Student attitude variables are constructive attitude, attitude in learning, independent attitude, scientific attitude, and learning attitude. While the students mathematics learning success variables are learning outcomes and learning achievement. The detailed characteristics of the study sample are presented in table 1 below. 
Table 1

Characteristics of study samples

\begin{tabular}{|c|c|c|c|c|c|}
\hline \multirow{2}{*}{ Year } & \multirow{2}{*}{ Author } & \multirow{2}{*}{$\mathrm{N}$} & \multirow{2}{*}{ Characteristics } & \multicolumn{2}{|l|}{ Variable } \\
\hline & & & & Independent & Dependent \\
\hline 2010 & Labib,F & 40 & Student SMA, Class X & $\begin{array}{l}\text { Constructive } \\
\text { attitude }\end{array}$ & Learning outcomes \\
\hline 2011 & Nurhayati & 320 & $\begin{array}{l}\text { Student SMP, Class } \\
\text { VIII }\end{array}$ & Learning attitude & Learning outcomes \\
\hline 2014 & Erviana, L & 235 & $\begin{array}{l}\text { StudentSMP, Class } \\
\text { VIII }\end{array}$ & $\begin{array}{l}\text { Attitudes on } \\
\text { subjects }\end{array}$ & Learning outcomes \\
\hline 2015 & $\begin{array}{l}\text { Susilo, T. A. B., \& Agustin, } \\
\text { I }\end{array}$ & 36 & $\begin{array}{l}\text { Student SMP, Class } \\
\text { VIII }\end{array}$ & $\begin{array}{l}\begin{array}{l}\text { Attitudes on } \\
\text { subjects }\end{array} \\
\end{array}$ & Learning outcomes \\
\hline 2015 & Jainuri, M & 18 & Student SMK, Class XI & Learning attitude & $\begin{array}{l}\text { Learning } \\
\text { achievement }\end{array}$ \\
\hline 2015 & Sulani \& Palupi, R.H & 62 & Student SMA, Class XI & Learning attitude & $\begin{array}{l}\text { Learning } \\
\text { achievement }\end{array}$ \\
\hline 2015 & Hakim, A. R & 130 & Student SMA, Class X & $\begin{array}{l}\text { Attitudes on } \\
\text { subjects }\end{array}$ & $\begin{array}{l}\text { Learning } \\
\text { achievement }\end{array}$ \\
\hline 2015 & $\begin{array}{l}\text { Ali, M.,Setyosari, } \\
\text { P.,Dwiyogo, } \\
\text { W. D., \& Napitupulu, M. }\end{array}$ & 144 & Student SMA, Class XI & $\begin{array}{l}\text { Attitudes on } \\
\text { learning }\end{array}$ & Learning outcomes \\
\hline 2016 & $\begin{array}{l}\text { Lambertus, Ambarsari, M., } \\
\& \text { Maonde, F }\end{array}$ & 90 & Siswa SMP, Class VIII & $\begin{array}{l}\text { Attitudes on } \\
\text { learning } \\
\end{array}$ & Learning outcomes \\
\hline 2016 & Purnomo, $\mathrm{P}$ & 72 & $\begin{array}{l}\text { Student SMP, Class } \\
\text { VIII }\end{array}$ & Learning attitude & $\begin{array}{l}\text { Learning } \\
\text { achievement }\end{array}$ \\
\hline 2016 & Hakim, A. R & 67 & $\begin{array}{l}\text { Student SMP, Class } \\
\text { VII }\end{array}$ & $\begin{array}{l}\text { Attitudes on } \\
\text { subjects }\end{array}$ & $\begin{array}{l}\text { Learning } \\
\text { achievement }\end{array}$ \\
\hline 2017 & Asmarani, D & 51 & $\begin{array}{l}\text { Student SMP, Class } \\
\text { VII }\end{array}$ & Learning attitude & Learning outcomes \\
\hline 2017 & Ma'mun, $\mathrm{K}$ & 56 & Student SMK, Class XI & $\begin{array}{l}\text { Attitude in } \\
\text { learning }\end{array}$ & $\begin{array}{l}\text { Learning } \\
\text { achievement }\end{array}$ \\
\hline 2017 & $\begin{array}{l}\text { Mujiono, L.A., \& } \\
\text { Ladyawati, E }\end{array}$ & 40 & $\begin{array}{l}\text { Student SMP, Class } \\
\text { VIII }\end{array}$ & $\begin{array}{l}\text { Independent } \\
\text { attitude }\end{array}$ & Learning outcomes \\
\hline 2018 & Rahman, A & 45 & $\begin{array}{l}\text { Student SMP, Class } \\
\text { VIII }\end{array}$ & $\begin{array}{l}\text { Attitude in } \\
\text { learning }\end{array}$ & $\begin{array}{l}\text { Learning } \\
\text { achievement }\end{array}$ \\
\hline 2018 & $\begin{array}{l}\text { Ventini,M., Hartati, } \\
\text { \& Sukardjo, M }\end{array}$ & 150 & Student SMA, Class XI & $\begin{array}{l}\text { Attitudes on } \\
\text { subjects }\end{array}$ & Learning outcomes \\
\hline 2019 & $\begin{array}{l}\text { Ningsih,S., Haryaka, U., } \\
\text { \& Watulingas, J.R }\end{array}$ & 183 & $\begin{array}{l}\text { Student SMP, Class } \\
\text { VII }\end{array}$ & Learning attitude & $\begin{array}{l}\text { Learning } \\
\text { outcomes }\end{array}$ \\
\hline 2019 & $\begin{array}{l}\text { Sirajuddin, Arsyad, N., \& } \\
\text { Ma'rufi }\end{array}$ & 130 & $\begin{array}{l}\text { Student MTS, Class } \\
\text { VIII }\end{array}$ & $\begin{array}{l}\text { Attitudes on } \\
\text { subjects }\end{array}$ & Learning outcomes \\
\hline 2019 & Biloa, W & 26 & Siswa SMP, Class VIII & $\begin{array}{l}\text { Attitudes on } \\
\text { subjects }\end{array}$ & Learning outcomes \\
\hline 2019 & Susilowati, T & 32 & $\begin{array}{l}\text { Student SMP, Class } \\
\text { VII }\end{array}$ & $\begin{array}{l}\text { Attitudes on } \\
\text { subjects }\end{array}$ & Learning outcomes \\
\hline 2019 & Haryaka, U \& Haslida & 360 & $\begin{array}{l}\text { Student SMP, Class } \\
\text { VII }\end{array}$ & Scientific attitude & Learning outcomes \\
\hline 2019 & Jemudin.,Makur., \& Ali & 46 & $\begin{array}{l}\text { Student SMP, Class } \\
\text { VII }\end{array}$ & Learning attitude & $\begin{array}{l}\text { Learning } \\
\text { achievement }\end{array}$ \\
\hline
\end{tabular}

Information:

SMP = Junior high school

MTs = Tsanawiyah School

SMA = Senior High School

SMK $=$ Vocational high School 


\section{Sampling Error Correction}

There are two stages in correction of sampling error, namely calculating the correlation correlation and calculating the population correlation variance. The results of the analysis are presented in table 2 and table 3 below.

Table 2

Average population correlation

\begin{tabular}{llll}
\hline Sample no & $\mathrm{N}$ & $\mathrm{r}_{\mathrm{xy}}$ & $\mathrm{N} \cdot \mathrm{r}_{\mathrm{xy}}$ \\
\hline 1 & 40 & 0,499 & 19,960 \\
\hline 2 & 320 & 0,327 & 104,64 \\
\hline 3 & 235 & 0,688 & 161,68 \\
\hline 5 & 36 & 0,475 & 17,100 \\
\hline 6 & 18 & 0,491 & 8,838 \\
\hline 7 & 62 & 0,521 & 32,302 \\
\hline 8 & 130 & 0,479 & 62,270 \\
\hline 9 & 144 & 0,258 & 37,152 \\
\hline 10 & 90 & 0,517 & 46,530 \\
\hline 11 & 72 & 0,675 & 48,600 \\
\hline 12 & 67 & 0,214 & 14,338 \\
\hline 13 & 51 & 0,307 & 15,657 \\
\hline 14 & 56 & 0,720 & 40,320 \\
\hline 15 & 40 & 0,606 & 24,240 \\
\hline 16 & 45 & 0,510 & 22,950 \\
\hline 17 & 150 & 0,639 & 95,850 \\
\hline 18 & 183 & 0,147 & 26,901 \\
\hline 19 & 130 & 0,283 & 36,790 \\
\hline 20 & 26 & 0,523 & 13,598 \\
\hline 21 & 32 & 0,566 & 18,112 \\
\hline 22 & 360 & 0,343 & 123,48 \\
\hline Total & 46 & 0,430 & 10,780 \\
\hline & 2333 & 10,218 & \\
\hline
\end{tabular}

Based on the table above, the mean population correlation values were obtained using the formula suggested by Hunter \& Schmidt (2004) below.

$$
r=\frac{\sum\left[N_{i} r_{x y}\right]}{\sum N_{i}}=\frac{991,088}{2333}=0,425
$$

The mean value of $\mathrm{r}$ is 0,425 which indicates there is a significant positive correlation between student attitudes and mathematics learning success. Calculating population correlation variance is a stage of analysis that must be considered. Variation of population correlation indicates a deviation from the correlation results of each study with the average correlation of all studies. Results of the analysis of population correlation variance are presented in table 3 below. 
Table 3

Population correlation variance

\begin{tabular}{llllrlc}
\hline Sample no & $\mathrm{N}$ & $\mathrm{r}_{\mathrm{xy}}$ & $\mathrm{N} . \mathrm{r}_{\mathrm{xy}}$ & $\left(\mathrm{r}_{\mathrm{xy}}-\mathrm{r}\right)$ & $\left(\mathrm{r}_{\mathrm{xy}}-\mathrm{r}\right)^{2}$ & $\mathrm{~N} .(\mathrm{rxy}-\mathrm{r})^{2}$ \\
\hline 1 & 40 & 0,499 & 19,960 & 0,055 & 0,003 & 0,121 \\
\hline 2 & 320 & 0,327 & 104,64 & $-0,117$ & 0,014 & 4,380 \\
\hline 3 & 235 & 0,688 & 161,68 & 0,244 & 0,060 & 13,991 \\
\hline 4 & 36 & 0,475 & 17,100 & 0,031 & 0,001 & 0,035 \\
\hline 5 & 18 & 0,491 & 8,838 & 0,047 & 0,002 & 0,040 \\
\hline 6 & 62 & 0,521 & 32,302 & 0,077 & 0,006 & 0,368 \\
\hline 7 & 130 & 0,479 & 62,270 & 0,035 & 0,001 & 0,159 \\
\hline 8 & 144 & 0,258 & 37,152 & $-0,186$ & 0,035 & 4,982 \\
\hline 10 & 90 & 0,517 & 46,530 & 0,073 & 0,005 & 0,480 \\
\hline 11 & 72 & 0,675 & 48,600 & 0,231 & 0,053 & 3,842 \\
\hline 12 & 67 & 0,214 & 14,338 & $-0,230$ & 0,053 & 3,544 \\
\hline 13 & 51 & 0,307 & 15,657 & $-0,137$ & 0,019 & 0,957 \\
\hline 14 & 56 & 0,720 & 40,320 & 0,276 & 0,076 & 4,266 \\
\hline 15 & 40 & 0,606 & 24,240 & 0,162 & 0,026 & 1,050 \\
\hline 16 & 45 & 0,510 & 22,950 & 0,066 & 0,004 & 0,196 \\
\hline 17 & 150 & 0,639 & 95,850 & 0,195 & 0,038 & 5,704 \\
\hline 18 & 183 & 0,147 & 26,901 & $-0,297$ & 0,088 & 16,142 \\
\hline 19 & 130 & 0,283 & 36,790 & $-0,161$ & 0,026 & 3,370 \\
\hline 20 & 26 & 0,523 & 13,598 & 0,079 & 0,006 & 0,162 \\
\hline 21 & 32 & 0,566 & 18,112 & 0,122 & 0,015 & 0,476 \\
\hline 22 & 360 & 0,343 & 123,48 & $-0,101$ & 0,010 & 3,672 \\
\hline Total & 46 & 0,430 & 19,780 & $-0,014$ & 0,000 & 0,009 \\
\hline & 2333 & 10,218 & 991,088 & 0,450 & 0,542 & 67,946 \\
\hline
\end{tabular}

Based on the table above, the population correlation variance values are obtained using the formula suggested by Hunter \& Schmidt (2004) below.

$$
\sigma_{r}^{2}=\frac{\sum\left[N_{i}\left(r_{x y}-r\right)^{2}\right]}{\sum N_{i}}=\frac{67,946}{2333}=0,029
$$

Correlation variance value of 0,029 means that the combined value of variance in population correlations and variance in sample correlations obtained from sampling errors. Correct variance correlation value is obtained from

$$
\sigma_{p o}^{2}=\sigma_{r}^{2}-\sigma_{e}^{2}=0,029-0,006=0,023
$$

The value of the population correlation variance of 0.023 means that the score of each population of each study studied has a small deviation from the average correlation of the population of the entire study. While the confidence interval is obtained by using a formula $r \pm 1,96 \sigma_{p o}=r \pm 0,297$, so obtained $0,128<r<0,722$. Thus the 
correlation value of 0,425 is within the region of receipt of the interval. In addition, the value of 0,425 is in the moderate category. Thus the attitude of students towards the achievement of learning mathematics is positively correlated.

The next stage in the meta-analysis is to calculate the weight of the effect size and make a confidence interval. The results of the analysis are shown in table 4 below.

Table 4

Tabulation of fixed effect model data

\begin{tabular}{lllllllll}
\hline $\mathrm{N}$ & $\mathrm{Rxy}$ & $\mathrm{Y}_{(\mathrm{Z})}$ & $\mathrm{V}_{\mathrm{y}}$ & $\mathrm{SEVy}_{\mathrm{y}}$ & $\mathrm{W}$ & $\mathrm{W} . \mathrm{Y}$ & $\mathrm{W}^{2} \mathrm{Y}^{2}$ & $\mathrm{~W}^{2}$ \\
\hline 40 & 0,499 & 0,548 & 0,027 & 0,164 & 37 & 20,275 & 11,110 & 1369 \\
\hline 320 & 0,327 & 0,339 & 0,003 & 0,056 & 317 & 107,611 & 36,530 & 100489 \\
\hline 235 & 0,688 & 0,844 & 0,004 & 0,066 & 232 & 195,842 & 165,320 & 53824 \\
\hline 36 & 0,475 & 0,517 & 0,030 & 0,174 & 33 & 17,045 & 8,804 & 1089 \\
\hline 18 & 0,491 & 0,537 & 0,067 & 0,258 & 15 & 8,061 & 4,332 & 225 \\
\hline 62 & 0,521 & 0,578 & 0,017 & 0,130 & 59 & 34,085 & 19,691 & 3481 \\
\hline 130 & 0,479 & 0,522 & 0,008 & 0,089 & 127 & 66,254 & 34,564 & 16129 \\
\hline 144 & 0,258 & 0,264 & 0,007 & 0,084 & 141 & 37,219 & 9,825 & 19881 \\
\hline 90 & 0,517 & 0,572 & 0,011 & 0,107 & 87 & 49,785 & 28,489 & 7569 \\
\hline 72 & 0,675 & 0,820 & 0,014 & 0,120 & 69 & 56,571 & 46,381 & 4761 \\
\hline 67 & 0,214 & 0,217 & 0,016 & 0,125 & 64 & 13,911 & 3,024 & 4096 \\
\hline 51 & 0,307 & 0,317 & 0,021 & 0,144 & 48 & 15,227 & 4,830 & 2304 \\
\hline 56 & 0,720 & 0,908 & 0,019 & 0,137 & 53 & 48,105 & 43,662 & 2809 \\
\hline 40 & 0,606 & 0,703 & 0,027 & 0,164 & 37 & 25,995 & 18,264 & 1369 \\
\hline 45 & 0,510 & 0,563 & 0,024 & 0,154 & 42 & 23,635 & 13,300 & 1764 \\
\hline 150 & 0,639 & 0,756 & 0,007 & 0,082 & 147 & 111,203 & 84,123 & 21609 \\
\hline 183 & 0,147 & 0,148 & 0,006 & 0,075 & 180 & 26,653 & 3,947 & 32400 \\
\hline 130 & 0,283 & 0,291 & 0,008 & 0,089 & 127 & 36,949 & 10,750 & 16129 \\
\hline 26 & 0,523 & 0,580 & 0,043 & 0,209 & 23 & 13,351 & 7,749 & 529 \\
\hline 32 & 0,566 & 0,642 & 0,034 & 0,186 & 29 & 18,607 & 11,939 & 841 \\
\hline 360 & 0,343 & 0,357 & 0,003 & 0,053 & 357 & 127,623 & 45,624 & 127449 \\
\hline 46 & 0,430 & 0,460 & 0,023 & 0,152 & 43 & 19,776 & 9,095 & 1849 \\
\hline
\end{tabular}

Based on the above table, the results of the transformation of sample correlation $(r)$ to fisher's $\mathrm{z}\left(\mathrm{Y}_{\mathrm{z}}\right)$ are obtained. It also obtained the variance $\mathrm{z}\left(\mathrm{V}_{\mathrm{Y}}\right)$ and standard error $\left(\mathrm{SE}_{\mathrm{Vy}}\right)$. The smallest standard error value is 0,053 and the largest standard error value is 0,258 . The results of the calculation of the total number of weights multiplied by the effect size divided by the total number of weights obtained by the average value of the effect size weight $(\mathrm{M})$ is 0,474 . Furthermore, the value of the variance of the weighted average $\left(\mathrm{V}_{\mathrm{M}}\right)$ is 0,00044 and the standard error (SEM) is 0,021. While the confidence interval is obtained by using the formula $M \pm 1,96 S E_{M}=M \pm 0,021$, so obtained $0,43<x<0,51$. Thus the average value of the effect size weight $(\mathrm{M})$, which is 0,474 in the area of the interval reception and is in the moderate category, so that the attitude of students and the achievement of learning mathematics gives a positive zize effect. 


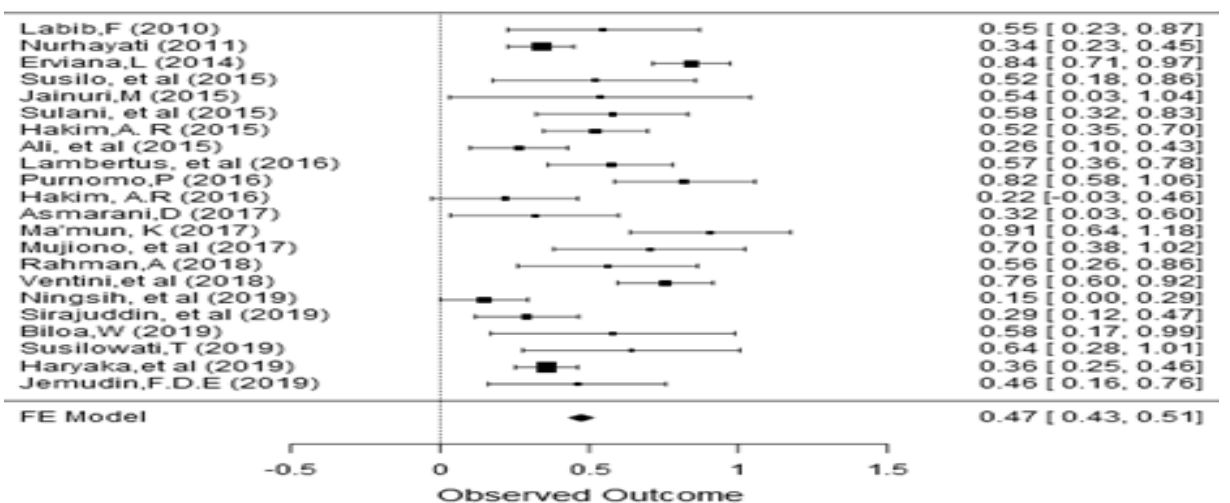

Figure 2

The forest plot summary effect

The next stage in the meta-analysis is to make a forest plot. The results of the analysis obtained forest plots for each study result marked by a square sign along the $\mathrm{x}$-axis. The order of each research result is displayed in accordance with the order of data from 2010 to 2019. The estimated effect size of the combined meta-analysis is indicated by the symbol (diamond) below the plot line and comprehensively visualizes, as well as the potential heterogeneity of research results (figure 2)

Based on the forest plot summary effect above it is known that the diamond width is 0,474 at a $95 \%$ confidence interval. While the confidence intervals for each study sample are indicated by their respective plots. The calculation result of $\mathrm{Z}$ value is 22,552; so that the p-value $<0,05$ is obtained. Based on the results of one-party test, there was a rejection of the null hypothesis (Ho). It can be said that students' attitudes significantly influence the success of learning mathematics.

The next stage in the meta-analysis is checking publication bias. The results of the bias analysis of 22 research publications on students' attitudes towards mathematics learning success can be seen in figure 3 below.

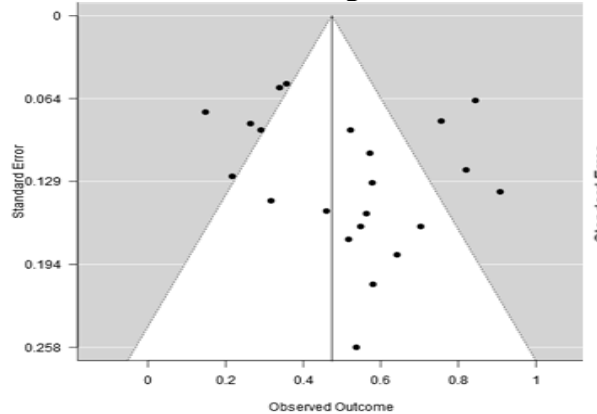

(a)

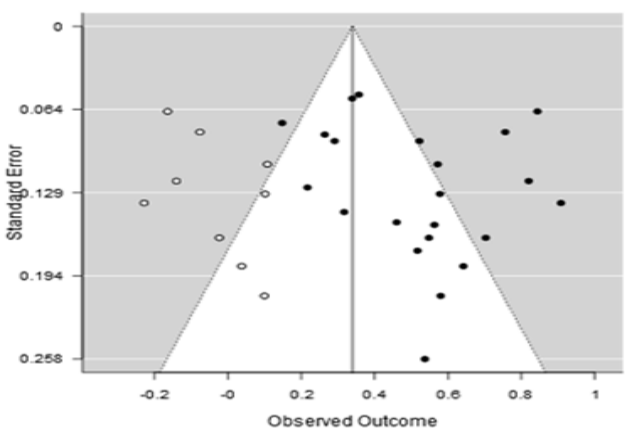

(b)

Figure 3

Funnel plot of the summary effect related to publication bias 
Figure 3 (a) shows the funnel plot prior to the addition of the publication. It appears that there is a publication bias. So that it can be said that in 22 research publications the influence of student attitudes on mathematics learning success found no evidence of publication bias. Whereas Figure 3 (b) shows the funnel plot after adding additional publications to the trim-fill analysis approach. It appears that the funnel was found asymmetrical. Addition will have a maximum impact on the effect size.

\section{DISCUSSION}

The results of a meta-analysis of 22 research publications in Indonesia, show that there is a positive and significant influence on students' attitude towards the success of learning mathematics. These results are in line with the results of Al-Mutawah \& Fateel research (2018) which states that attitude towards mathematics are positively and significantly correlated with academic achievement in mathematics. This significant correlation is due to the small variance value of the weighted average (VM) of 0,00044 and the standard error (SEM) of 0,021. These results certainly prove the consistency and strengthen the theories or findings of previous researchers. Mathematical learning attitude, attitude in learning mathematics, scientific attitude, independent attitude, attitude to mathematics lessons, and constructive attitude are components of student attitude variables that correlate to the success of learning mathematics. While learning outcomes and mathematics learning achievements are measures of student learning success variables.

The mean value of 0,474 is the weight of the effect size of the effect of students' attitudes on mathematics learning success. The effect size weights are in the moderate category (Cohen, et. al, 2007). Thus, the positive attitudes of students towards mathematics is one of the factors that in influence students' willingness to learn mathematics, so that mathematics learning goals can be achieved and students get high math scores.

The success of learning mathematics obtained by previous students will have an impact on the success of subsequent mathematics (Kiss, 2018). Attitude toward mathematics can be improved through the learning process approach (Perry, et al., 2016). Good mathematics learning needs to be supported by the teacher's ability to deliver material, choose models, approaches, and learning methods. The selection of the right mathematics learning model can make students happy, active, innovative, creative, and independent in the learning process. Thus the material learned or taught will be easily understood by students. Information about students' attitudes towards the success of students mathematics learning can help teachers in mathematics in the learning process.

Many factors affect student attitudes including family, strengthening of parents and teachers, teaching, and school / classroom climate (Papanastasiou, 2002). In addition, students' mathematical attitudes are influenced by three factors: First; Content coverage includes teaching materials, content emphasis, task orientation, and task based on daily life situation. Second; teaching practice is instructional method. The three teaching qualities are classroom management, classroom organization, and learning environment (Ayob \& Yasin, 2017). 
The variation in correlation values obtained between student attitude and mathematics learning success is due to the measurement of student attitude variables that are subjective and difficult. Attitude measurement generally uses a non-test instrument (questionnaire) with a Likert scale. While the measurement of student learning success uses the test of learning outcomes or mathematics learning achievement. According to Hamdi, Kartowagiran, \& Haryanto (2018) that measurement is related to several things that occur during the learning process, especially evaluation and assessment. Thus the measurement of student attitude and mathematics learning success is related to evaluation and assessment. Apart from this, student attitude variables are considered very important in the success of learning mathematics (Diggs, 2016). Based on a sample of research publications, there were 14 publications related to the influence of students' attitudes toward learning outcomes and 8 publications related to learning achievement. This provides information that research related to student attitudes is very attractive to researchers in Indonesia. The results of checking publication bias with meta-analysis found evidence of publication bias, so it is necessary to add publications in the analysis to maximize effect size. But according to Grasman (2017) that the method still causes a lot of contradiction or debate from the meta-analysis experts.

\section{CONCLUSION}

Students' attitudes is very important in achieving success in learning mathematics, because attitude is a factor that originates in students. Researchers generally measure students' attitudes using non-test instruments, while students' tests are used to determine students' learning success. Measures of student learning success are learning outcomes and mathematics learning achievements. Correlation values from each sample of research publications affect the attitude of students to the success of learning mathematics, used as data in meta-analysis. The sample data used has varying coefficients and is positive. A meta-analysis study has provided information that there is a positive and significant influence on students' attitudes toward mathematics learning success with an effect size weight value of 0,474 in the moderate category. The weight value of the effect size is between 0,453 to 0,495 intervals. This significant correlation is due to the small sampling error. In addition, the value of the variance of the weighted average $\left(\mathrm{V}_{\mathrm{M}}\right)$ is 0,00044 and the standard error (SEM) which is 0,021 is still relatively low. These results certainly prove and strengthen the theories or findings of previous researchers. But the results of this study still have sample size limitations. The sample taken does not represent the population of students in Indonesia. In addition, the need for additional publications in the analysis is desired to avoid publication bias and obtain a maximum effect size.

The meta-analysis research has shown the consistency of the publication of the results of research on the influence of students attitude towards the success of learning mathematics in Indonesia, so that the variable of student attitudes should be a concern of teachers in teaching mathematics material at every level of formal education. Teachers in learning must be able to foster students' mathematical attitude. 


\section{REFERENCES}

Al-Mutawah, M. A., \& Fateel, M. J. (2018). Students' achievement in math and science: how grit and attitudes influence?. International Education Studies, 11(2), 97-105.

Atiyah, M. (1993). Mathematics: quen and servant of the sciences. Procedings of the American Philosophical Society, 137(4), 527-531.

Ali, M., Setyosari, P., Dwiyogo, W. D., \& Napitulu, M. (2015). Hubungan antara presepsi siswa terhadap kompetensi guru, konsep diri, sikap dan hasil belaja rmatematika siswa di SMA Kota Palu. Journal Inovasi dan Teknologi Pembelajaran, $1(2), 165-181$.

Asmarani, D. (2017). Pengaruh sikap terhadap hasil belajar matematika siswa kelas VII SMP Negeri 23 Merangin. Mat-Eduakasi: Journal Pendidikan Matematika, 2(1),31-36.

Ayob, A., \& Yasin, R. M. (2017). Factor affecting attitudes towards mathematic. International Journal of Academic Research in Busines and Social Sciences, 7(11), 1100-1109.

Biloa, W. (2019).The Relationship between attitude towards mathematics and learning outcomes at mathematics subject at grade VIII at SMP Negeri 7 Gorontalo. (Thesis).Gorontalo State University.

Borenstein, M.,Hedges, L. V., Higgins, J.P.T.,\&Rothstein, H. R. (2009). Introduction to meta-analysis.John Wiley \& Sons, Ltd. United Kingdom.

Capuno, R., Necesario, R., Etcuban, J. O., Espina, R., Padilo, G., \& Manguilimotan. (2019). International Electronic Journal of Mathematics Education, 14(3), 547-561

Cohen, L., Manion, 1., \& Morrison, K. (2007). Research methods in education. Sixth edition. Madison Avenue: New York.

Diggs, C. R., \& Akos, P. (2016).The promise of character education in middle school: a meta-analysis. Middle Grades Review. 2(2).1-19.

Erviana, L. (2014). The influence of learning interset, attitude, and student perception on teaching methoed of teacher toward mathematics learning outcame of the Eight Grade students at state secondaryschools in Bulukumba. (Thesis).Makassar State University.

Grasman, R. (2017). Meta-analysis in JASP.Web publication/site, JASP.Retrieved from https://jaspstats.org/2017/11/15/meta-analysis-jasp.

Hakim, R. A. (2015). Analisis prestasi belajar matematika ditinjau dari kecerdasan spritual dan sikap peserta didik pada mata pelajaran matematika. Seminar nasional pendidikan matematika, Universitas Indrapasta PGRI, 47-54.

Hakim, A. R. (2016). Judging from the Mathematics learning achievement attitude and commitment task learners in math lessons. JKPM, 2(1), 24-36. 
Hamdi, S., Kartowagiran, B., \& Haryanto. (2018). Developing a testlet model for mathematics at elementary level. International Journal of Instruction, 11(3), 375-390.

Haryaka, U., \& Haslidia. (2019). Pengaruh konsep diri, minat, dan sikap ilmiah siswa terhadap hasil belajar matematika. PRISMA, Prosiding seminar nasional matematika 2, 737-747.

Hunter, J. E.,\& Schmidt, F. L. (2004). Methods of meta-analysis: Correcting error and bias in research findings. Thousand Oaks: California.

Jainuri, M. (2015). Pengaruh sikap dan tingkat intelegensi terhadap prestasi belajar matematika siswa kelas II SMK Tri Bhakti Banko. (https://www.academia).

Jemudin, F.D.E.,Makur, A.P., \& Ali, F.A. (2019). Hubungan sikap belajar dan motivasi belajar terhadap prestasi belajar matematika siswa SMPN 6 Langke Rembong. Journal of Honai Math., 2(1), 1-11.

Kirkham, J., Chapman, E., \& Wildy, H. (2019). Factors considered by Western Australian Year 10 students in choosing Year 11 mathematics courses. Mathematics Education Research Journal. https://doi.org/10.1007/s13394-019-00277-y

Kiss, A. (2018). Investigating young children's attitudes toword mathematics: improved measurement and the relation to achievement. (Dissertation), university of minnesota.

Labib, F. (2010).Pengaruh sikap konstruktif peserta didik pada pembelajaran matematika terhadap hasil belajar matematika materi pokok logaritma kelas X IPA. (Skripsi). IAIN Walisongo: Semarang.

Lambertus, Ambarsari, M., \& Maonde, F. (2016). The effect of students' attitude on the theirmaths achievement through the combination of cooperative learning models. JurnalPendidikanMatematika, 7(2), 105-124.

Ma'mun, K. (2017). Korelasi antara prestasi belajar dengan sikap siswa dalam pembelajaran matematika kurikulum 2013 pada siswa kelas XI SMK Se-Kecamatan Purworejo. (Skripsi). Program Studi Pendidikan Matematika:Universitas Muhammadiyah Purworejo.

Makur, A. P., Prahmana, R. C. I., \& Gunur, B. (2019). How mathematics attitude of mother ini rural area affects their children's achievement. In Journal of Physics: Conference series, 1188(1), p.012009. IOP Publishing.

Mazana, \& Mzomwe, Y. (2019). Investigating students' attitude towards learning mathematic. International Electronic Journal of Mathematics Education, 14(1), 207231.

Mujiono, L. A., \&Ladyawati.(2017). Hubungan motivasi dan sikap mandiri terhadap hasil belajar matematika pada materi fungsi kelas VIII SMP. Seminar Nasional Pendidikan Matematika, Universitas PGRI Adi Buana Surabaya. 5 36-541.

Nurhayati. (2011). Pengaruh sikap dan kebiasaan terhadap hasil belajar matematika. Jurnal Formatif, 1(3), 247-254. 
Ningsih, S., Haryaka, U., \& Watulingas, J. R. (2019). Pengaruh motivasi, lingkungan belajar, dan sikap siswa terhadap hasil belajar matematika siswa kelas VII SMP Negeri 22 Samarinda. Jurnal PRIMATIKA, 8(1), 43-54

Papanastasiou, C. (2002). School, teaching and family influence on student attitudes toward science: Based on TIMSS data for Cyprus. Studies in Educational Evaluation, 28(1), 71-86.

Perry, S. M., Catapano, M., \& Ramon, O. G. (2016). Teaching, Academic Ahievement, and attitudes toward mathematic in the United States and Nigeria. Journal for Leadership and Instruction, 15(2), 5-12.

Peteros, E., Columna, D., Etcuban, J. O., Almerino, P., \& Almerino, J. G. (2019). Attitude and academic achievement of high school student in mathematics under the conditional cash transfer program. International Electronic Journal of Mathematics Education, 14(3), 583-597.

Purnomo, Y. (2016). The impact of student's attitude on mathematic and student's learning independence on mathematical learning achievement. JKPM, 1(1),93-105

Rahman, A. (2018). Hubungan motivasi dan sikap siswa terhadap prestasi belajar matematika kelas VIII SMP Negeri 1 Wera. Journal Pendidikan MIPA, 8(1), 60-66

Slameto. (1995). Belajar dan faktor-faktor yang menpengaruhinya. Jakarta: PT. Rineka Cipta.

Sirajuddin, Asyad, N., \& Ma'rufi. (2019). Pengaruh sikap pada pelajaran matematika terhadap hasil belajar matematika siswa. Pedagogy, 4(1), 13-19

Sulani, \& Palupi, R.H. (2015). Pengaruh sikap belajar dan peran orang tua terhadap prestasi belajar matematika kelas XI IPA SMA Negeri 1 Campurdarat Tulungagung Tahun pelajaran 2014/2015.Jurnal Pendidikan dan Pembelajaran Matematika (JP2M), 1(1), 46-57.

Susilo, T. A. B., \& Agustin, I. (2015). Effect of math attitude in students on math learning achievement in SMP. Journal Pendidikan Matematika STKIP PGRI Sidoarjo, 3(1), 9-16.

Susilowati, T. (2019). Hubungan sikap siswa dengan hasil belajar matematika. Ekuivale. 38-42.

Ozturk, A.Y. (2014). The effects of alternative assessment and evaluation method applied in fifth grade mathematics course on academic achievement, presistence of learning, self-efficacy percetion and attitudes. (Doctoral Thesis). Canakkale 18 Mart University, Canakkale.

Ventini, M., Hartati, \&Sukardjo, M. (2018). Hubungan kecerdasan emosional dan sikap terhadap pelajaran matematikadengan hasil belajar matematika siswa SMA Jakarta Timur. Journal TeknologiPendidikan, 20(2), 166-180.

World Development Report. (2018). Learning to education's promise. Washinton, DC.doi: 10.1596/978-1-4648-1097-8 